\title{
Women-owned family businesses in transitional economies: key influences on firm innovativeness and sustainability
}

\author{
Lisa K Gundry ${ }^{1 *}$, Jill R Kickul ${ }^{2}$, Tatiana lakovleva ${ }^{3}$ and Alan L Carsrud ${ }^{4}$
}

\author{
* Correspondence: \\ lgundry@depaul.edu \\ ${ }^{1}$ Driehaus College of Business, \\ Center for Creativity \& Innovation, \\ DePaul University, 1 E. Jackson Blvd., \\ Suite 7000, Chicago, IL 60604, USA \\ Full list of author information is \\ available at the end of the article
}

\begin{abstract}
This research presents an examination of familial influence on strategic entrepreneurial behaviors within a transitional economic context. Utilizing a large sample of women-led family businesses, the study investigates the relationships between risk-taking propensity, entrepreneurial intensity, and opportunity recognition of the entrepreneur and the innovative orientation of the firm and sustainability. A model of the influences on innovativeness and sustainability in family firms is developed, and the potential contribution of the present study is the identification of constructs that facilitate these strategic outcomes and behaviors that drive growth. The degree to which family firms can create new products, services, and processes that add value to their marketplace can strongly influence their sustainability, especially in an emerging economy.
\end{abstract}

Keywords: Family business; Women entrepreneurs; Innovation; Sustainability; Emerging economy; Opportunity recognition

\section{Background}

Research conducted within the transitional economies of Central and Eastern Europe has shown that models of entrepreneurship have high transferability to these cultures (Gibb 1993; Gundry and Ben-Yoseph 1998; Kickul et al. 2010). Entrepreneurial firms are at the forefront of economic development in emerging economies (Neace 1999); as such, the influences on the growth and sustainability of these enterprises are of research and public policy interest. Numerous studies identifying the success factors of small and medium-sized enterprises (SMEs) have been conducted in developed countries (Anna et al. 2000; Chaganti and Parasuraman 1997; Lerner and Almor 2002). However, more research utilizing rigorous scientific approaches is needed (Tkachev and Kolvereid 1999).

The study on women entrepreneurs and women in family firms can trace their start to the mid-1980s (Carsrud and Olm 1986; Hagan et al. 1989; Chrisman et al. 1990). Since that time, there has been an increasing interest in women entrepreneurs and the challenges they faced in developed economies (Marlow 1997; Carter and Allen 1997; Baker et al. 1997; Berg 1997; Cole 1997). The presence of women leading small and entrepreneurial organizations has had a powerful impact on the global business landscape and employment (Minnitti et al. 2005; Diana Project 2005). However, research 
on women entrepreneurs in transitional economies is less developed (Tkachev and Kolvereid 1999), and the positive impact of female entrepreneurs is not always recognized to the same degree by countries in transition (Welter and Smallbone 2010). Scholars have acknowledged that with regard to gender and entrepreneurship, policymakers and financial experts in any particular country should not uncritically rely on research results from other countries (Eriksson et al. 2009; Welter 2011). Bruton et al. (2008) pointed out a need to develop a deeper understanding of entrepreneurship in emerging economies. Furthermore, the lack of information on successful female entrepreneurs, especially running family firms, is especially apparent.

The study extends previous work by using a large sample of women-led family businesses in order to examine familial influence on strategic entrepreneurial behaviors, including opportunity recognition and innovativeness. This study examines whether family influence affects the relationships between risk-taking propensity, entrepreneurial intensity, and opportunity recognition of the entrepreneur and the innovative orientation of the firm and sustainability. The degree to which family firms can create new products, services, and processes that add value to their marketplace can strongly influence their sustainability, especially in an emerging economy.

This paper is structured as follows: first, we discuss family firms in entrepreneurship research and the usage of family and gender as explanatory variables. Next, family business research within transitional economies is discussed, with focus on the Russian context. The theoretical constructs employed in this research are summarized, and the research model is presented. The 'Methods' section with description of the sample, research instrument, and operationalization of the constructs is followed by results of the analysis and discussion, and implications for future scholarship and practice in this area.

\section{Family firms and entrepreneurial research}

The academic study on family business is usually tied to the founding of Family Business Review in 1987 (Carsrud and Brännback 2012). The characteristics, capabilities, and resources of family firms can influence entrepreneurial orientation, including innovation and risk-taking behaviors (Zahra 2005), making family firms an excellent context in which to examine entrepreneurial processes (Zahra et al. 2004; Dyer 2006; Naldi et al. 2007; Nordqvist et al. 2008). Furthermore, as noted by Naldi et al. (2007), more research is needed on the relationship between entrepreneurial orientation and firm outcomes within family firms.

Research on family firms also has tended to focus on male founders and successors (Hall et al. 2001; Steier 2001), while many other topics have been largely ignored (Carsrud and Brännback 2012). Perricone et al. (2001) have shown that most successors are first-born males. However, the empirical study on leadership in family firms remains largely understudied (Renko et al. 2012). Family business research continues to lack unified theories (Carsrud and Brännback 2012) but is still identified by a few key themes such as succession, intergenerational conflict, growth, and corporate and family governance (Miller and Le Breton-Miller 2003; Sonfield and Lussier 2004; Carsrud and Brännback 2012). The field of family business cannot even agree on a definition of what constitutes a family business or even a family (Carsrud et al. 1996; 
Chrisman et al. 1996; Chua et al. 1999; Carsrud 2006; Carsrud and Brännback 2012). If the study on women entrepreneurs and women in family businesses is to advance, more empirical research needs to be done based on both existing research and welltested theories that can work across genders and using objective and measurable operational definitions of concepts.

\section{Using family and gender as explanatory variables}

To understand family as an explanatory factor in entrepreneurial family firms in transitional economies requires looking at the relationship between two systems (family and firm). Here is where the concept of family influence (Habbershon et al. 2003) can provide both a theoretical basis and research evidence. This concept can be of use in understanding women-led family firms and the attractiveness of such firms in terms of social, human, and financial capital (Carter and Rosa 1998). While such an approach has its merits, it still suffers from the attempt to turn essentially a loosely defined demographic variable (family) into a causal factor. Is family really a unitary concept or is it in fact a multi-faceted term that serves as a quick reference for a variety of factors such as generations, values, religion, ethnicity, culture, etc.? In other words, when one uses the term family, one is subsuming a number of factors within that term. Is the impact of family or family influence due to values, cultural background, organizational structure, the number of family members in the firm, who leads it, or the number of generations involved (Carsrud and Brännback 2012)? To advance social science, one needs to add precision to the definition of family influence and family as they are most likely multi-dimensional variables for purposes of research studies. The current study is limited to the definition provided by the subjects' self-reports. While this may limit the generalizations and explanations available from the current study, if individuals selfidentify as a family firm, then one can assume they perceive family to be an important influence, or identity, in the firm.

Family context may have a special importance for women entrepreneurs. Recent literature suggests that for women, work-life balance is a more complex and demanding task, involving family embeddedness as the main issue (Brush et al. 2009). Jennings and McDougal (2007) suggested the term 'motherhood' as a metaphor representing the household/family context. Brush et al. (2009) argued that motherhood or family/household contexts might have a larger impact on women than men, while Welter and Smallbone (2010) illustrated that this context might be very different depending on the country of operation. For example, in a recent study of entrepreneurial intentions in two developed and two developing countries, it was found that the highest barrier for starting a business is indeed risk related (Iakovleva et al. 2013). However, that was not the case for developing countries, where risk barrier was ranked second or third. It was concluded that in more turbulent environments, people generally rely less on government or existing jobs. Thus, risk relating to owning and running a business is perceived lower in comparison with developed countries, where being an employee provides far more benefits and security. In their study of Russian and Ukrainian women entrepreneurs, (Iakovleva et al., unpublished work) found that developing countries often do not provide the same institutional conditions for working women during their maternity leave. This reduces the benefits of being employed in relation to running a 
business, which provides more flexibility. This might have direct implications for the models explain behavior of family-owned firms as well, where it is often suggested that such firms are less risk oriented based on the results of empirical findings from developed countries. Thus, in the present study, we suggest using gender as a lens to explore behavior of female entrepreneurs in family-owned firms.

\section{Family business research in transitional economies}

The generalization of existing entrepreneurship research findings outside developed nations (Carsrud 1992) remains lacking despite the impact of the Global Entrepreneurship Monitor (GEM) Project (Minnitti et al. 2005). The current study bridges this gap by including women-headed organizations self-classified as either family or non-family businesses in the rural parts of a country in transition to a market economy - Russia. Research in Central and Eastern Europe show current models of entrepreneurship, and new venture creation strategies may be transferable to these transitional economies if a holistic approach is used to facilitate learning and development (Gundry and Ben-Yoseph 1998). While Chrisman et al. (2002) and Carsrud et al. (2007) suggest that the family may have a strong influence on perceptions and performance of the firms they own and manage, questions remain (Carsrud and Brännback 2012). To what extent does this family influence translate into differences in entrepreneurial orientation, including risk taking, entrepreneurial intensity, opportunity recognition, and innovation strategies deployed by the business? How do these in turn impact sustainability of the firm, and are these different in transitional economies? These are the key questions to be examined in the present study.

\section{Entrepreneurship in the Russian context}

Entrepreneurs in a transitioning economy may face continuing challenges and obstacles, including unpredictable and often hostile external environments, and resource scarcity, especially financial resources (Smallbone and Welter 2001). Research on entrepreneurship in transition economies over the last two decades has included research on start-ups in Poland (Erutku and Vallée 1997), venture capital in Hungary, Poland, and Slovakia (Karsai et al. 1998), as well as studies on the growth of women-owned firms in Turkey (Esim 2000; Hisrich and Ozturk 1999) and entrepreneurs in India (Mitra 2002).

In comparison to other transition economies such as India and China, the development of the small business sector in Russia has been somewhat slower (Verkhovskaya et al. 2007). For example, the number of SMEs per 10,000 inhabitants is 6.0 in Russia (Zhuplev 2009). By comparison, in the EU, there are approximately 30 registered SMEs per 10,000 inhabitants.

In part, this is explained by the operating environment for entrepreneurs and small businesses that can involve extensive bureaucracy, corruption, weakly developed financial markets, and poor governmental support mechanisms for beginning entrepreneurs (Karhunen et al. 2008; Verkhovskaya et al. 2007). In addition, poor management, a lack of knowledge and experience, and the culture of market relations hinder the development of entrepreneurship (Kickul et al. 2010; Iakovleva et al., unpublished work). Russia's transition from a centrally planned to a market economy began in the early 1990s (Ogloblin 1999). Twenty-plus years later, SMEs in Russia are a key part of the country's sustainable 
economic development. SMEs constitute 20-25\% share in GSP with high growth potential forecasted (European Investment Bank, 2013).

During the past decade, positive changes in relation to entrepreneurship support systems and funding opportunities have been observed in Russia. In recent Russian banking history, there were two periods when banks targeted SMEs and entrepreneurs. The first period was in the late 1990s, when the European Bank for Reconstruction and Development mostly granted credit to micro and small businesses. However, in 2000 this program was closed. Nearly 10 years later a new wave targeting small business began, and today banks offer a wide range of services, including loans, for the SME sector. However, the interest rate for loans is quite high, and many start-ups chose to use other, informal, sources of funding (Iakovleva et al. 2013). Although few in number, there are programs to support entrepreneurs with venture capital, mortgages, or business incubation. One example is non-repayable subsidies of 300,000 RUB (approximately equivalent to 7,000 euros) to start a business. For SMEs at the development stage, there is, for example, a special program to cover the first lease payment or leasing interest for those who need equipment. To support innovation, there are programs covering patent payments, certification, or R\&D costs. There are also programs at the federal level intended to promote a positive image of entrepreneurship. For a country with no tradition of entrepreneurship, it is important that people understand that business owners create work places, attract investment, and pay tax. However, there is an absence of any programs or initiatives to promote women entrepreneurs in Russia. Also, when it comes to funding availability, banks do not differentiate on gender; rather, the payment history and general business conditions are estimated (Iakovleva et al. 2013).

Most Russian entrepreneurs are between 30 to 50 years of age (Wells et al. 2003; Turen 1993); $70 \%$ to $80 \%$ have higher levels of education (Babaeva 1998; Wells et al. 2003). Women entrepreneurs in Russia have yet to follow worldwide trends similar to those found in other national studies on women entrepreneurs. By various estimates, the enterprises managed by women provide $50 \%$ to $52 \%$ of the national GDP in Germany and in the USA, $52 \%$ to $55 \%$ in Japan, and $57 \%$ to $60 \%$ in Italy (Gorbulina 2006), suggesting that women in these countries are fairly well integrated in economic development. However, in Russia it is estimated that women entrepreneurs only represent $30 \%$ to $40 \%$ of the total. According to Ylinenpåå and Chechurina (2000), societal limitations in other fields may ultimately serve as factors propelling women to enter the entrepreneurial sector, where starting new ventures serves the dual purpose of generating additional family income and increasing self-fulfillment. However, it is clear that they have yet to achieve the percentages found in more developed economies.

In the current market economy, those women entrepreneurs have adapted and sought to acquire knowledge and information rapidly. As noted above, Russian women generally have a high level of education and many possess more than one degree from institutions of higher education. This characteristic, along with the ability to establish relationships, leads to steadier levels of employment and higher income generation in women-owned companies (Gorbulina, 2006). First-generation Russian women entrepreneurs succeeded in a highly dynamic environment in the transition to the market economy. As economic conditions stabilize, new opportunities are emerging for women (Kickul et al, 2010).

Since entrepreneurial businesses first emerged following the fall of the Soviet Union, first-generation Russian women entrepreneurs have succeeded in a highly dynamic 
environment in the transition to the market economy. As economic conditions stabilize and new opportunities emerge for these entrepreneurs, the ability of firms to survive and grow requires an entrepreneurial orientation. The present study expands previous work to propose a theoretically driven model exploring the role of entrepreneurial orientation in the innovation and sustainability of women-led family firms in a transitional economy.

\section{Entrepreneurial orientation in family firms: the roles of risk taking, entrepreneurial intensity, and recognizing new opportunities for innovation}

Organizations that exhibit an entrepreneurial orientation tend to engage in risk-taking behavior, including incurring debt and making large resource commitments with the expectation of high return (Lumpkin and Dess 1996). Casillas and Moreno (2010) studied the influence of family involvement on entrepreneurial orientation and growth, and results showed that family involvement increases the influence of innovativeness on growth and, at the same time, decreases the influence of risk taking on growth. In the family business context, researchers have found that family firms are less inclined to undertake risk, perhaps because the survival of the firm is of utmost importance; this seems to be especially true in emerging and underdeveloped economies (Zahra 2005; Gomez-Mejia et al. 2007).

While entrepreneurs are likely to be committed to their entrepreneurial endeavor, some entrepreneurs can be characterized as having a single-minded focus to work towards the growth of the venture, often at the expense of other worthy and important goals - known as entrepreneurial intensity. In a study on entrepreneurs in high- and low-growth firms, intensity was found to discriminate among entrepreneurs on the basis of actual growth rates: high-growth entrepreneurs were significantly more motivated to do whatever it takes to grow their enterprises and ensure new venture success (Gundry and Welsch 2001).

\section{Opportunity recognition in the context of family firms}

The motivation of the entrepreneur has been shown as an important factor associated with superior firm performance (Carsrud et al. 1989; Carsrud and Brännback 2011); static personality characteristics and other individual traits have not been proven less effective at predicting performance (Sandberg and Hofer 1987). The ability to identify opportunities is very valuable for entrepreneurs as they are able to recognize and develop market opportunities, strengthening the competitive advantage of their firms (Chandler and Hanks 1994; Carsrud and Brannback 2007). Opportunity identification involves identifying new market opportunities for products and services, discovering new ways of improving existing products, and forecasting customers' unmet needs (De Noble et al. 1999). Opportunity recognition is a process of perceiving a possibility to create a new business or to significantly improve the position of an existing business, and in both cases, new profit potential emerges (Christensen et al. 1994).

Similarly, innovativeness is perceived as a highly relevant component of entrepreneurial orientation in the family firm context (Nordqvist et al. 2008; Zellweger and Sieger 2012). Innovation can be defined as the effective application of new products and processes designed to benefit the organization and its stakeholders (West and Anderson 1996; 
Wong et al. 2009). According to Damanpour (1996), innovation is a means of transforming an organization in response to changes in the external environment or, proactively, to influence the environment. Based on a multidisciplinary analysis, scholars recently proposed an integrative definition of innovation as a multistage process in which firms transform ideas into new or improved products, services, or processes to compete and differentiate themselves in the marketplace (Baregheh et al. 2009).

Researchers have postulated that family firms tend to have a longer-term orientation and, thus, may have well-developed entrepreneurial strategies for innovation, especially if the entrepreneur has a strong orientation towards innovativeness and can make decisions more rapidly given the structure of the family firm (James 1999; Mustakallio and Autio 2002; Zahra et al. 2004; Casillas and Moreno 2010). Entrepreneurial innovativeness can be directed towards achieving specific firm outcomes, including sustainability. Given the general long-term orientation of family firms, it is of research interest to investigate the influences of entrepreneurial orientation and firm innovativeness on the sustainability of a family-led organization.

\section{Sustainability}

Sustainability is often described as a measure of an organization's ability to fulfill its mission and serve its stakeholders over a longer period of time and to have a recognizable and measurable impact. Improved sustainability can lead to broader sources of funding and enhances the firm's ability to provide value over an extended period of time (Bryson 2004; Carsrud and Brännback 2010). The process of achieving sustainability is designed to achieve specific, identifiable goals toward a specific impact and not an end into itself. Sustainability involves all the elements and functions of an organization and every major decision made within the organization (Chen and Singh 1995; Bryson 2004; Carsrud and Brännback 2010). Sustainability has been characterized by capacity and adaptability (York 2012). There are four components of a sustainable firm: (1) the adaptive capacity to monitor, assess, and respond to both internal and external changes; (2) the leadership capacity to make decisions and to provide the direction necessary to achieve the organization's goals; (3) the management capacity to employ resources efficiently and, typically, in a resource-constrained environment, and (4) the technical capacity (skills, experience, and knowledge) needed to implement the programmatic, organizational, and community strategies (Bryson 2004; Carsrud and Brännback 2010; York 2012).

A firm's focus on sustainability leads to a greater emphasis on long-term viability and impact, and it relies on an approach to innovation that effectively applies new processes in ways that benefit the stakeholders of the organization (West and Anderson 1996; Wong et al. 2009). By introducing innovative processes and practices, sustainable organizations are able to adapt to challenging scenarios and can operate in resourceconstrained environments (Carsrud and Brännback 2010).

\section{Research model}

The present study focuses on a large sample $(N=310)$ of Russian female entrepreneurs heading family firms. Previous research indicates that Russian women often attribute their entrance into entrepreneurship to 'push' factors, such as the need to generate 
family income and create an arena for self-fulfillment (Minnitti et al. 2005; Reynolds and White 1997), and they are able to identify growth opportunities (Iakovleva and Kickul 2007). Although some of the findings in the literature discussed above regarding growth orientation and innovativeness of family firms are sometimes contradictory, we suggest that the turbulent environment of the Russian economy provides stimulus for women entrepreneurs to perform opportunity-oriented behavior. Previous research has shown that risk taking, among other proactive behaviors, and innovativeness influence growth in family firms (Casillas and Moreno 2010). Based on the above discussion, risk-taking propensity and entrepreneurial intensity leading to opportunity recognition are important antecedents of innovativeness which in turn is seen as key to obtaining firm sustainability. The following research model is proposed (Figure 1).

A potential contribution of the present study is the identification of constructs that facilitate innovativeness and firm sustainability in these family businesses. These are depicted in the model below. This approach may help practitioners and policy makers formulate and implement new strategies and programs supporting women entrepreneurs. These findings are especially important to the discovery of ways to support female-led family businesses within turbulent transition economies as they innovate and achieve sustainable business performance.

\section{Results}

Descriptive statistics and intercorrelations among the study variables are provided in Table 1. As mentioned, the model was tested using SEM. The fit statistics for our proposed model suggested an adequate fit to the data $\left(\chi^{2}(5)=33.50\right.$, goodness of fit index $(\mathrm{GFI})=.96$, comparative fit index $(\mathrm{CFI})=.90$, incremental fit index $(\mathrm{IFI})=.90)$.

Table 2 presents the total, direct, and indirect effects of risk-taking propensity and entrepreneurial intensity on the endogenous variables in the model. The total effects match the standardized regression coefficients derived from regressing an endogenous variable on risk taking and entrepreneurial intensity. As displayed in Table 2, the significant risk taking and entrepreneurial intensity total effects were completely indirect based on our model as they were transmitted through opportunity recognition and innovation. Mediation would be supported if the fit of the model would not be improved by the addition of direct paths from risk-taking propensity and entrepreneurial intensity to sustainability. The addition of these paths did not improve the model fit. This indicates that personal characteristics such as risk taking and intensity are factors

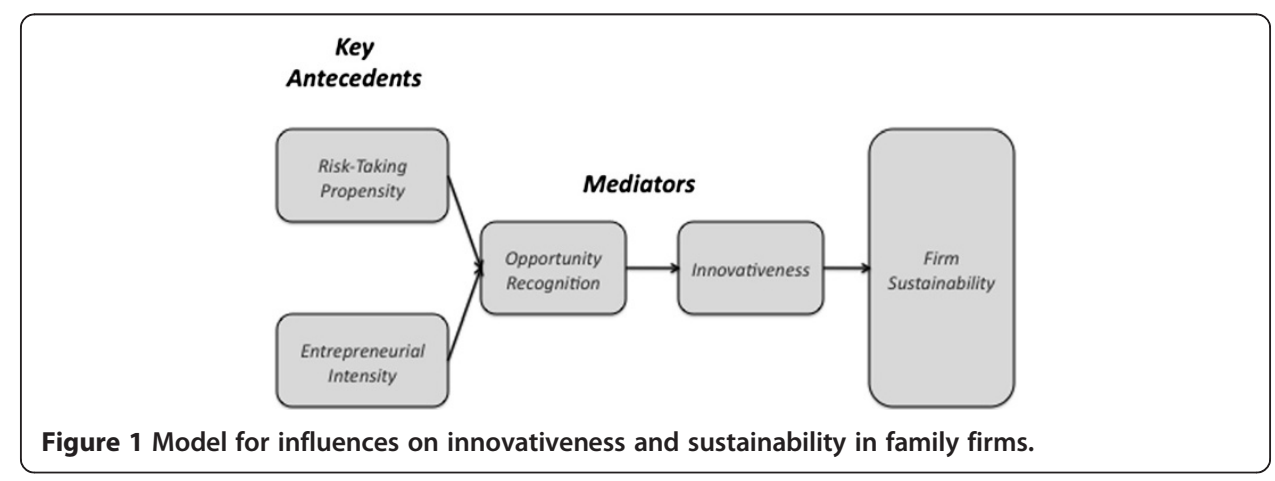


Table 1 Means, standard deviations, zero-order correlations, and reliabilities of measures

\begin{tabular}{llllllll}
\hline Variable & Mean & SD & $\mathbf{1}$ & $\mathbf{2}$ & $\mathbf{3}$ & $\mathbf{4}$ & $\mathbf{5}$ \\
\hline 1. Risk-taking propensity & 4.46 & 2.21 & $(.89)$ & & & & \\
2. Entrepreneurial intensity & 6.26 & 1.83 & $.13^{*}$ & $(.88)$ & & & \\
3. Opportunity recognition & 7.65 & 2.36 & $.32^{* *}$ & $.36^{* *}$ & $(.63)$ & & \\
4. Innovation & 4.27 & 1.91 & $.29^{* *}$ & $.15^{*}$ & $.37^{* *}$ & $(.77)$ & \\
5. Sustainability & $(-)$ & $(-)$ & $.16^{*}$ & $.16^{*}$ & $.39^{* *}$ & $.49^{* *}$ & $(.95)$ \\
\hline
\end{tabular}

Firm sustainability measure was standardized. ${ }^{*} p<.05 ;{ }^{* *} p<.01$. Dashes indicate data are not applicable.

only as they impact opportunity recognition and innovation. To illustrate, with a model that includes direct paths from risk taking and entrepreneurial intensity to sustainability, the chi-square dropped by only 2.88 ( 2 degrees of freedom), and the other fit statistics (e.g., GFI, CFI, IFI) were virtually unchanged. Mediation was therefore supported the effects of risk taking and entrepreneurial intensity on sustainability were mediated by opportunity recognition and innovation. This notion that 'personality and motivational factors' operate via other behaviors to impact firm performance has been found previously (Carsrud et al. 1989; Carsrud and Brännback 2011).

Unlike much previous research on family firms which typically show reduced levels of risk taking, the current findings revealed that Russian female entrepreneurs within family firms exhibited both risk-taking attitudes and an entrepreneurial intensity. These then led them to seek and find new opportunities and implement these opportunities and innovations for the marketplace. It is possible that the current research is reflecting the early stage of these ventures, but it does challenge the notion that family firms are less risk oriented. The findings revealed that both opportunity recognition and innovativeness fully mediated the relationship between risk taking and entrepreneurial intensity and firm sustainability, that is, these key antecedents leading to venture sustainability of a venture were consistently structured, valued, and in place for these women-led family firms.

\section{Discussion}

While this study clearly needs to be replicated with other samples of female entrepreneurs running family-owned firms within emerging economies, this study has allowed a

Table 2 Direct, indirect, and total effects

\begin{tabular}{llll}
\hline & Effect & Direct & Indirect \\
\cline { 2 - 4 } & Total & $.30^{* *}$ & \\
\hline Risk-taking propensity & $.30^{* *}$ & & .09 \\
Opportunity recognition & .09 & .14 \\
Innovation & .14 & $.42^{* *}$ & \\
Sustainability & & & .13 \\
Entrepreneurial intensity & $.42^{* *}$ & & .19 \\
Opportunity recognition & .13 & & \\
Innovation & .19 & & \\
Sustainability & & & \\
\hline
\end{tabular}

${ }^{*} p<.05 ;{ }^{*} p<.01$. The effects are controlling for the other effects in the models. 
view into what drives sustainability and growth in new family firms run by women in an emerging economy. It is certainly possible that the cultural context in this study, Russia, does have an impact on the risk taking being displayed and subsequent impact on opportunity recognition and innovation. For example, a culture that does not prize innovation may therefore not see this as important behaviors to exhibit even if it is important to subsequent entrepreneurial performance and firm sustainability. The Russian culture has certainly prized education and scientific innovation; therefore, one would expect that risk-taking attitudes would be found to impact firms via innovation, given the cultural support for such behaviors.

It is interesting to explore the extent to which our results correlate with findings from other research. Although Hofstede's measures of uncertainty avoidance are quite high for Russia with a value of 95 compared to the average of 50 for developed countries (Hofstede 2001), other research asserts that Iakovleva this general measure does not indeed reflect risk in relation to establishing or operating a business. In fact, it was found that start-up intentions are higher in developing countries (Iakovleva et al. 2011) and that risk is perceived as a higher barrier in developed countries (Iakovleva et al., unpublished work)). Thus, although Russia is relatively low with regard to the measurement of total entrepreneurial activity ${ }^{\mathrm{a}}(\mathrm{TEA}=4.6)$ in comparison to an average of 14.1 for factor-driven economies (Bosma et al. 2011), risk is perceived as a less important barrier in comparison to financing (Iakovleva et al., unpublished work). Our findings from the present research confirm positive propensity toward risk taking among Russian family businesses.

This paper adds to the literature on the impact of cognitive/psychological factors of entrepreneurs. It shows that the impact is not direct as many early researchers proposed and yet were unable to demonstrate (Sandberg and Hofer 1987), but in fact operate as indirect influences on firm performance as proposed by Carsrud et al. (1989) and Carsrud and Brännback (2011). This shows that risk taking and intensity are critical to subsequent opportunity recognition and innovation. Those factors in turn are critical to firm sustainability. The implications of this research suggest that entrepreneurs can be encouraged to undertake appropriate risks, even in environments where obstacles exist, as a means to embrace opportunities in the marketplace. If they do so effectively, they contribute to the sustainability of their organizations. More work is needed here to promote the development of entrepreneurial instruction and support programmes towards this goal, helping entrepreneurs identify and pursue objectives critical to sustainability of their ventures.

This paper adds to both our understanding on family-owned firms and family firms owned and managed by women. It is clear that in the Russian context of the early twenty-first century, such firms' sustainability is impacted by the risk-taking attitudes and entrepreneurial intensity of their women leaders. This may be due to the nature of that particular emerging economy, as these findings support the recent comparison between developing and developed countries (Bosma et al. 2011; Iakovleva et al. 2011). However, our findings also suggest that in newer family firms run by women, opportunity recognition and innovation are critical to survival and growth. A recent study on Russian female entrepreneurs suggests that they often need to be very competitive and make bold decisions, and the challenge of being women in a turbulent environment adds to the necessity for taking calculated risks (Iakovleva et al. 2013). The present 
study shows that Russian women are very capable of exhibiting those behaviors in order to sustain their self-identified family firms. The traditional myth of risk aversion often seen in more established economies and firms may not hold in emerging economies, with family firms headed by women. This is an example of the kinds of myths and assumptions that family business researchers need to challenge and which can only be done by looking beyond the traditional samples in Western developed economies with large established family firms (Carsrud and Brännback 2012).

\section{Conclusions}

Examining the influences on innovative behavior in family firms can contribute to our understanding on how these businesses strategically prepare for, and implement, new innovations for sustainability. Without overstating our results, and underscoring that additional research needs to be conducted to further the work in this field, the , inclusion of a large sample of female-led family businesses adds to the growing body of literature on the role and contribution of women business owners to the global economy, and to their families and communities in particular, something long called for by academics (Hagan et al. 1989). If entrepreneurship and family firms are critical to all economies - both established and emerging, then more research like this which examines variables that impact those firms must be done, especially in emerging economies not only in Eastern Europe and Russia, but also in Africa.

The ever evolving competitive environments in transitional economies render seemingly sustainable strategic advantages obsolete. Instead, competitive advantages arise from a family firm's capability to constantly redeploy, reconfigure, rejuvenate, and innovate their capabilities in responding to the changing environmental conditions.

\section{Methods}

Participants were entrepreneurs of 310 Russian women-led family firms. The data were obtained from the Russian Women's Micro-financial Network (RWMN). The mission of the RWMN is to support the development of sustainable women-focused, locally managed microfinance institutions (MFIs) throughout Russia by creating an effective financial and technical structure that provides high-quality services to partner MFIs over the long term. RWMN operates in six regions in Russia: Kostroma, Tver, Kaluga, Belgorod, Vidnoe, and Tula, with the head office in Moscow. Each division is an independent local organization that provides micro loans for clients, with no less than $51 \%$ of clients being women.

The survey was pretested with the assistance of seven native-speaking Russian women entrepreneurs who commented on each question. Data were collected by the workers of local divisions during face-to-face interviews with respondents. Descriptive statistics are presented in Table 3. The sample mainly consists of sole proprietorships with $94 \%$ of businesses having no more than ten employees (and 60\% having just two employees), being woman-led and woman-owned (95\%), operating mainly in the service industry (80\%), with $56 \%$ of the enterprises self-reporting as being family businesses. This profile differs from the typical Russian SME profile with regard to gender, educational background, industry structure, legal form, number of employees, and family 
Table 3 Participant characteristics

\begin{tabular}{lll}
\hline Variables & Number & Percent \\
\hline Respondents & & \\
Average respondent age & 40 years & 49 \\
Higher education - yes & 252 & 14 \\
Entrepreneurial experience of relatives - yes & 76 & 96 \\
Enterprises & & 56 \\
Independent business - yes & 24 & \\
Family business - yes & 310 & \\
Average firm age & 8 & 5 \\
Average number of employees & 4 & 80 \\
Industry & & 15 \\
Manufacturing & 28 & \\
Trade and catering consumption & 442 & \\
Service & 81 &
\end{tabular}

business issues (Iakovleva 2005; Bezgodov 1999). One might consider these as earlystage, small family firms.

Firm sustainability was based on measures by Chandler and Hanks (1994) and Westhead et al. (2005). Respondents were asked to indicate the degree of importance their enterprise attached to the following items over the past 3 years: sales level, sales growth, turnover, profitability, net profit, gross profit, and the ability to fund enterprise growth from profits. Then they were asked how satisfied they were with the same indicators over the past 3 years. The questions are those slightly modified versions used by Iakovleva (2005) based on those from Chandler and Hanks (1994) and Westhead et al. (2005). The questions were transformed after consulting with Russian entrepreneurs to assure clarity of the meaning of the questions. Based on these 14 questions, a composite firm sustainability index was constructed following the principle used in expectancy theory and later in the theory of planned behavior (Ajzen 1991). Questions about importance were rescaled from a 7-point Likert scale ( 1 to 7 ) to a -3 -to-3 scale, and then satisfaction and importance scores were multiplied. A principal component analysis was then done, which resulted in one factor which we called firm sustainability (please see Table 4 for additional analyses).

Risk-taking propensity was assessed by taking two items taken from Miller and Friesen (1982). The items were rescaled to a 7-point one-sided Likert scale to be in the same format as the other questions: 'owing to the nature of the environment, bold, wide-ranging acts are viewed as useful and common practice', and 'we have a strong proclivity for profitable, but risky, projects.'

Entrepreneurial intensity is the degree to which entrepreneurs are willing to exert maximum motivation and effort towards the success of their venture. The Entrepreneurial Intensity scale was adapted from the Entrepreneurial Profile Questionnaire, successfully implemented in a variety of research sites in the USA, Mexico, Russia, Poland, Romania, and Hungary (Pistrui et al. 1998; Welsch and Pistrui 1993 ; Welsch and Roberts 1994). A sample item measuring this construct is 'my business is the most important activity in my life' (Gundry and Welsch 2001).

For opportunity recognition, six items were taken from De Noble et al. (1999): ability to see new market opportunities for new products, ability to discover new ways to 
Table 4 PCA for composite sustainability

\begin{tabular}{lll}
\hline Variables & Factor loadings & Communality \\
\hline Composite sustainability & & \\
Sales level satisfaction $\times$ importance & 0.87 & 0.76 \\
Sales growth satisfaction $\times$ importance & 0.89 & 0.80 \\
Turnover satisfaction $\times$ importance & 0.87 & 0.75 \\
Profitability satisfaction $\times$ importance & 0.90 & 0.81 \\
Net profit satisfaction $\times$ importance & 0.88 & 0.78 \\
Gross profit satisfaction $\times$ importance & 0.88 & 0.78 \\
Ability to fund business from the profit satisfaction $\times$ importance & 0.80 & 0.64 \\
Eigenvalue & 5.31 & \\
Percent variance explained & 75.85 & \\
Cronbach's alpha & 0.95 & \\
\hline
\end{tabular}

Factor loadings 0.3 or smaller are suppressed. $\mathrm{KMO}=0.925$, Bartletts's test of sphericity App. chi-square $3392.079 ; \mathrm{df}=21$, sig. 000.

improve existing products, ability to design products that solve current problems, ability to create products that fulfill customers' unmet needs, ability to identify new areas for potential growth, and ability to bring a product concept to the market in a timely manner. These items were measured according to the recommendations by Bandura (2001). The respondents were asked to indicate their degree of confidence in performing the tasks successfully. The scale ranged from $0=$ 'no confidence at all', to $5=$ 'some confidence', to $10=$ 'complete confidence'. Finally, innovativeness was assessed using three items from Chandler and Hanks (1994): 'we strive to be the first to have new products available, 'we stress new product development', and 'we engage in novel and innovative marketing techniques'.

Structural equation modeling (SEM) was used to test a sequence of models that examined the mediating effects of opportunity recognition and innovativeness on the relationships (paths) between risk-taking propensity, entrepreneurial intensity, and firm sustainability (Joreskog and Sorbom 1993). We used SEM as it effectively estimates model parameters. Lisrel 8.7 (Joreskog and Sorbom 1993) was used. SEM serves a similar purpose as multiple regression analyses but also takes into account the modeling of interactions, nonlinearities, and correlated independents, provides information on the degree of fit of the tested model, and controls for measurement error. Therefore, SEM is often considered as the preferred causal modeling method (e.g., James et al. 2006). We used the correlation matrix and standard deviations as input to estimate of the structural model. Aggregation was conducted for each common construct to have unidimensional composite scales for the structural model (Anderson and Gerbing 1988).

We acknowledge that common method variance could be a factor given our use of survey instruments for data collection. Tests were conducted, and those analyses did not indicate that as an issue in this study.

\section{Endnote}

${ }^{a}$ Early-stage entrepreneurial activity rate (TEA) taken from the GEM report. This indicator includes percentage of the 18 to 64 age group who are either a nascent entrepreneur or owner-manager of a new business. 


\section{Competing interests}

The authors declare they have no competing interests.

\section{Authors' contributions}

LG contributed to the study design, literature review and discussion.JK contributed to the study design, data analysis and discussion, TI contributed to the literature review, data collection and discussion. AC contributed to the literature review, discussion and conclusions. All authors read and approved the final manuscript.

\section{Author details}

${ }^{1}$ Driehaus College of Business, Center for Creativity \& Innovation, DePaul University, 1 E. Jackson Blvd., Suite 7000, Chicago, IL 60604, USA. ${ }^{2}$ NYU-Stern Program in Social Entrepreneurship, Berkley Center for Entrepreneurship and Innovation, Stern School of Business, New York University, 40 W 4th Street, Tisch 4-24, New York, NY 10012, USA. ${ }^{3}$ Centre for Innovation Research, UiS Business School, University of Stavanger, Stavanger N-4036, Norway. ${ }^{4}$ Ábo Akademi School of Business and Economics, Åbo Akademi University, Henriksgatan 7, Turku FIN-20500, Finland.

Received: 20 February 2013 Accepted: 29 January 2014

Published: 26 March 2014

\section{References}

Ajzen, I. (1991). The theory of planned behavior. Organizational Behavior and Human Decision Processes, 50, 179-211.

Anderson, J. C., \& Gerbing, D. W. (1988). Structural equation modeling in practice: a review and recommended two-step approach. Psychological Bulletin, 49, 411-423.

Anna, A. L., Chandler, G. N., Jansen, E., \& Mero, N. P. (2000). Women business owners in traditional and non-traditional industries. Journal of Business Venturing, 15, 279-303.

Babaeva, L. (1998). Russian and American female entrepreneurs. The Sociological Review, 8, 134-135.

Baker, T., Aldrich, H., \& Liou, N. (1997). Invisible entrepreneurs: the neglect of women business owners by mass media and scholarly journals in the United States. Entrepreneurship and Regional Development, 9, 221-238.

Bandura, A. (2001). Social cognitive theory: an agentic perspective. Annual Review of Psychology, 54(1), 1-26.

Baregheh, A., Rowley, J., \& Sambrook, S. (2009). Towards a multidisciplinary definition of innovation. Management Decision, 47(8), 1323-1339.

Berg, N. (1997). Gender, place and entrepreneurship. Entrepreneurship and Regional Development, 9(3), 259-268.

Bezgodov, A. (1999). Entrepreneurship sociology. St. Petersburg: Petropolis.

Bosma, N., Wennekers, S., \& Amoros, J. (2011). Global entrepreneurship monitor 2011. Extended report: entrepreneurs and entrepreneurial employees across the globe. www.gemconsortium.org/. Accessed 16 July 2012.

Brush, C., de Bruin, A., \& Welter, F. (2009). A gender-aware framework for female entrepreneurship. International Journal of Gender and Entrepreneurship, 1(1), 8-24.

Bruton, G. D., Ahlstrong, D., \& Obloj, K. (2008). Entrepreneurship in emerging economies: where are we today and where should the research go in the future. Entrepreneurship: Theory \& Practice, 32(1), 1-14.

Bryson, J. M. (2004). Strategic planning for public and nonprofit organizations: a guide to strengthening and sustaining organizational achievement. San Francisco: Jossey-Bass.

Carsrud, A. L. (1992). Entrepreneurship and enterprise formation: a brief perspective on the infrastructure in Europe. Entrepreneurship: Theory and Practice, 15(3), 69-75.

Carsrud, A. L. (2006). Commentary: "Are we family and are we treated as family? Nonfamily employees' perceptions of justice in the family firm": it all depends on perceptions of family, fairness, equality, and justice. Entrepreneurship: Theory and Practice, 30(6), 855-860.

Carsrud, A., \& Brannback, M. (2007). Entrepreneurship. Westport: Greenwood.

Carsrud, A. L., \& Brännback, M. (2010). Fostering sustainability in family firms. In R. Kao (Ed.), Sustainable economy: corporate, social and environmental responsibility (pp. 53-70). Singapore: World Publications.

Carsrud, A., \& Brännback, M. (2011). Reflections on twenty years of research on entrepreneurial motivation: have we learned anything at all? Journal of Small Business Management, 49(1), 9-26.

Carsrud, A., \& Brännback, M. (2012). Where have we been and where should we be going in family business research. In A. Carsrud \& M. Brännback (Eds.), Understanding family business: unique perspectives, neglected topics, and undiscovered approaches (pp. 1-8). Heidelberg: Springer.

Carsrud, A. L., \& Olm, K. W. (1986). The success of male and female entrepreneurs: a comparative analysis of the effects of multi-dimensional achievement motivation and personality traits. In R. Smilor \& R. L. Kuhn (Eds.), Managing take-off in fast growth firms (pp. 147-162). New York: Praeger.

Carsrud, A., Olm, K., \& Thomas, J. (1989). Predicting entrepreneurial success: effects of multi-dimensional achievement motivation, levels of ownership, and cooperative relationships. Entrepreneurship and Regional Development, 1(3), $237-244$.

Carsrud, A., Perez, S. E., \& Sachs, R. (1996). Exploring a classification scheme for closely-held businesses: getting to workable definitions of family firms. In Proceedings of the World Conference of the Family Business Network. Edinburgh.

Carsrud, A. L., Brannback, M., Kickul, J., Krueger, N., \& Elfving, J. (2007). The family pipeline: where norms and modeling make a difference in entrepreneurial intentions. Philadelphia: Academy of Management.

Carter, N. M., \& Allen, K. (1997). Size determinants of women-owned businesses: choice or barriers to resources? Entrepreneurship and Regional Development, 9(3), 211-220.

Carter, S., \& Rosa, P. (1998). The financing of male- and female-owned businesses. Entrepreneurship and Regional Development, 10(3), 225-242.

Casillas, J. C., \& Moreno, A. M. (2010). The relationship between entrepreneurial orientation and growth: the moderating role of family involvement. Entrepreneurship and Regional Development, 22(3-4), 265-291. 
Chaganti, R., \& Parasuraman, S. (1997). A study of the impacts of gender on business performance and management patterns in small business. Entrepreneurship: Theory and Practice, 21(2), 73-76.

Chandler, G., \& Hanks, S. (1994). Founder competence, the environment, and venture performance. Entrepreneurship: Theory and Practice, 18(3), 77-89.

Chen, L., \& Singh, S. (1995). Sustainability of the Children's summit goals: concepts and strategies. Florence: UNICEF.

Chrisman, J. J., Carsrud, A. L., DeCastro, J., \& Herron, L. (1990). A comparison of assistance needs of male and female pre-venture entrepreneurs. Journal of Business Venturing, 5(4), 235-248.

Chrisman, J., Chua, J., \& Sharma, P. (1996). A review and annotated bibliography of family business studies. Norwell: Kluwer Academic.

Chrisman, J., Chua, J., \& Steier, L. (2002). The influence of national culture and family involvement on entrepreneurial perceptions and performance at the state level. Entrepreneurship: Theory and Practice, 26(4), 113-130.

Christensen, P., Madsen, O., \& Peterson, R. (1994). Conceptualizing entrepreneurial opportunity identification. In G. E. Hills (Ed.), Marketing and entrepreneurship: research ideas and opportunities. London: Quorum.

Chua, J., Chrisman, J., \& Sharma, P. (1999). Defining the family firm by behavior. Entrepreneurship: Theory and Practice, 23(4), 19-39.

Cole, P. M. (1997). Women in family business. Family Business Review, 10(4), 53-71.

Damanpour, F. (1996). Organizational complexity and innovation: developing and testing multiple contingency model. Management Science, 42(5), 693-716.

De Noble, A. F., Jung, D., \& Ehrlich, S. B. (1999). Entrepreneurial self-efficacy: the development of a measure and its relation to entrepreneurial action. In P. D. Reynolds, W. D. Bygrave, S. Manigart, C. M. Mason, G. D. Meyer, H. J. Sapienza, \& K. G. Shaver (Eds.), Frontiers of entrepreneurship research (pp. 73-87). Babson College: Wellesley.

Diana Project. (2005). The Diana international project: research on growth oriented women entrepreneurs and their businesses. Stockholm: ESBRI. http://www.esbri.se/diana.asp. Accessed 06 August 2006.

Dyer, W. G. (2006). Examining the "family effect" on firm performance. Family Business Review, 19(4), 253-273.

Eriksson, P., Katila, S., \& Niskanen, M. (2009). Gender and sources of finance in Finish SMEs: a contextual view. International Journal of Gender and Entrepreneurship, 1(3), 176-190.

Erutku, C., \& Vallée, L. (1997). Business start-ups in today's Poland: who and how? Entrepreneurship and Regional Development, $9(2), 113-126$.

Esim, S. (2000). Solidarity in isolation: urban informal sector women's economic organizations in Turkey. Middle Eastern Studies, 1, 140-152.

European Investment Bank. (2013). Small and medium entrepreneurship in Russia. November http://www.eib.org/ attachments/efs/econ_study_small_and_medium_entrepreneurship_in_russia_en.pdf. Accessed 28 March 2014

Gibb, A. A. (1993). Small business development in central and eastern Europe: opportunity for a rethink? Journal of Business Venturing, 8(6), 461-486.

Gomez-Mejia, L. R., Haynes, K. T., Nunez-Nickel, M., Jacobson, K. J. L., \& Moyano-Fuentes, J. (2007). Socioemotional wealth and business risks in family-controlled firms, Evidence from Spanish olive oil mills. Administrative Science Quarterly, 52(1), 106-137.

Gorbulina, I. (2006). Women's small and medium enterprises - path to overcome poverty. Paper presented at Women Leaders Network Meeting. Hanoi, Vietnam. http://www.apecwln.org/2008/01/wln-2006-resource-materials/. Accessed 28 March 2014

Gundry, L. K., \& Ben-Yoseph, M. (1998). Women entrepreneurs in Romania, Poland, and the U.S: cultural and family influences on strategy and growth. Family Business Review, 11(4), 61-75.

Gundry, L. K., \& Welsch, H. P. (2001). The ambitious entrepreneur: high-growth strategies of women-owned enterprises. Journal of Business Venturing, 16(5), 453-470

Habbershon, T., Williams, M., \& MacMillan, I. (2003). A unified systems perspective of family firm performance. Journal of Business Venturing, 18(4), 451-465.

Hagan, O., Rivchun, C. A., \& Sexton, D. (1989). Women business-owners. Cambridge: Ballinger.

Hall, A., Melin, L., \& Nordqvist, M. (2001). Entrepreneurship as radical change in the family business: exploring the role of cultural patterns. Family Business Review, 14(3), 193-208.

Hisrich, R., \& Ozturk, S. A. (1999). Women entrepreneurs in a developing economy. The Journal of Management Development, 18(2), 114-125.

Hofstede, H. (2001). Culture's consequences: comparing values, behaviours, institutions and organizations across nations (2nd ed.). Thousand Oaks: Sage.

lakovleva, T. (2005). Entrepreneurial orientation of Russian SME. In G. T. Ving \& R. C. W. Van der Voort (Eds.), The emergence of entrepreneurial economics (pp. 83-98). Bingley UK: Emerald Group Publishing Ltd.

lakovleva, T., \& Kickul, J. (2007). Personal and organizational success factors of women SMEs in Russia. In M. Dowling \& J. Schmude (Eds.), Empirical entrepreneurship in Europe. Northampton, MA: Edward Elgar.

lakovleva, T., Kolvereid, L., \& Stephan, U. (2011). Entrepreneurial intentions in developing and developed countries. Education and Training, 53(5), 353-370.

lakovleva, T., Solesvik, M., \& Trifilova, A. (2013). Financial availability and government support for women entrepreneurs in transitional economies: Cases of Russia and Ukraine. Journal of Small Business and Enterprise Development, 20(2), $314-340$.

lakovleva, T., Kolvereid, L., Sørhaug, O., \& Gorvievski, M. (unpublished work). Perceived barriers to entrepreneurship: comparison of developing and developed European countries. International Journal of Entrepreneurship and Innovation Management,

James, H. S. (1999). Owners as managers, extended horizons and the family firm. International Journal of the Economics of Business, 6(1), 41-55.

James, L. R., Mulaik, S. A., \& Brett, J. M. (2006). A tale of two methods. Organizational Research Methods, 9, 233-244.

Jennings, J. E., \& McDougal, M. S. (2007). Work-family interface experiences and coping strategies: implications for entrepreneurship research and practice. The Academy of Management Review, 32(3), 747-760.

Joreskog, K. G., \& Sorbom, D. (1993). LISREL VIII: a guide to the program and applications. Chicago: SPSS. 
Karhunen, P., Kettunen, E., Sivonen, T., \& Miettinen, V. (2008). Determinants of knowledge intensive entrepreneurship in Southeast Finland and Northwest Russia. Finland: Helsinki School of Economics, Mikkeli Business Campus Publications N-77 Mikkeli.

Karsai, J., Wright, M., Dudzinski, Z., \& Morovic, J. (1998). Screening and valuing venture capital investments: evidence from Hungary, Poland and Slovakia. Entrepreneurship and Regional Development, 10(3), 189-202.

Kickul, J., Griffith, M., Gundry, L., \& lakovleva, T. (2010). Mentoring women entrepreneurs in the Russian emerging market. In C. Brush, A. Bruin, E. Gatewood, \& C. Henry (Eds.), Women entrepreneurs and the global environment for growth. A research perspective (pp. 303-322). Northampton: Edward Elgar.

Lerner, M., \& Almor, T. (2002). Relationships among strategic capabilities and the performance of women-owned small ventures. Journal of Small Business Management, 40(2), 109-125.

Lumpkin, G. T., \& Dess, G. G. (1996). Clarifying the entrepreneurial orientation construct and linking it to performance. The Academy of Management Review, 21(1), 135-172.

Marlow, S. (1997). Self-employed women: new opportunities, old challenges? Entrepreneurship and Regional Development, 9(3), 199-210.

Miller, D., \& Friesen, P. H. (1982). Innovation in conservative and entrepreneurial firms: two models of strategic momentum. Strategic Management Journal, 3, 1-25.

Miller, D., \& Le Breton-Miller, I. (2003). Challenge versus advantage in family business. Strategic Organization, 1(1), 127-134.

Minnitti, M., Arenius, P., \& Langowitz, N. (2005). 2004 Report on women and entrepreneurship. Global entrepreneurship monitor. Wellesley: The Center for Women's Leadership at Babson College.

Mitra, R. (2002). The growth pattern of women-run enterprises: an empirical study in India. Journal of Developmental Entrepreneurship, 7(2), 212-237.

Mustakallio, M., \& Autio, E. (2002). Governance, entrepreneurial orientation, and growth in family firms. In M. Koiranen \& N. Karlsson (Eds.), The future of family business: values and social responsibility. 13th Annual Family Business Network World Conference, September 11-14 2002 (pp. 219-38). Jyvaskyla: University of Jyvaskyla School of Business and Economics.

Naldi, L., Nordqvist, M., Sjberg, K., \& Wiklund, J. (2007). Entrepreneurial orientation, risk taking, and performance in family firms. Family Business Review, 20(1), 33-47.

Neace, M. B. (1999). Entrepreneurs in emerging economies: creating trust, social capital, and civil society. The Annals of the American Academy of Political and Social Science, 565(1), 148-161.

Nordqvist, M., Habbershon, T. G., \& Melin, L. (2008). Transgenerational entrepreneurship: exploring EO in family firms. In H. Landstrom, H. Crijns, \& E. Laveren (Eds.), Entrepreneurship, sustainable growth and performance: frontiers in European entrepreneurship research (pp. 93-116). Cheltenham: Edward Elgar.

Ogloblin, C. G. (1999). The gender earnings differential in the Russian transitional economy. Industrial and Labor Relations Review, 52(4), 602-627.

Perricone, P., Earle, J., \& Taplin, I. (2001). Patterns of succession and continuity in family-owned businesses: study of an ethnic community. Family Business Review, 14(2), 105-122.

Pistrui, D., Liao, J., Welsch, H., Pistrui, D., Liao, J., \& Welsch, H. (1998). Entrepreneurial expansion plans: an empirical investigation of infrastructure predictors. In Paper presented at Research in Entrepreneurship (RENT XII), Lyon, 26-27 November, 1998.

Renko, M., El Tarabishy, A., Carsrud, A., \& Brännback, M. (2012). Entrepreneurial leadership in the family business. In A. Carsrud \& M. Brännback (Eds.), Understanding family business: undiscovered approaches, unique perspectives, and neglected topics (pp. 169-184). Heidelberg: Springer.

Reynolds, P., \& White, S. (1997). The entrepreneurial process: economic growth, men, women, and minorities. Quorum: Westport.

Sandberg, W., \& Hofer, C. (1987). Improving new venture performance: the role of strategy, industry structure, and the entrepreneur. Journal of Business Venturing, 2, 5-28.

Smallbone, D., \& Welter, F. (2001). The distinctiveness of entrepreneurship in transition economies. Small Business Economics, 16, 249-262.

Sonfield, M., \& Lussier, R. (2004). First-, second-, and third-generation family firms: a comparison. Family Business Review, 17(3), 189-202.

Steier, L. (2001). Next generation entrepreneurs and succession: modes and means of managing social capital. Family Business Review, 14(3), 259-276.

Tkachev, A., \& Kolvereid, L. (1999). Self-employment intentions among Russian students. Entrepreneurship and Regional Development, 11(3), 269-280.

Turen, A. (1993). Russian entrepreneurship: experience of sociological analysis. Moscow: Russia.

Verkhovskaya, O. R., Dermanov, V. K., Dorohina, M. V., \& Katkalo, V. S. (2007). Global entrepreneurship monitoring, country report on Russia 2006. St. Petersburg: St. Petersburg State University, Higher School of Management.

Wells, B. L., Pfantz, T. J., \& Bryne, J. L. (2003). Russian women business owners: evidence of entrepreneurship in a transition context. Journal of Developmental Entrepreneurship, 8(1), 59-71.

Welsch, H., \& Pistrui, D. (1993). Entrepreneurship commitment and initiative in Romania. In Paper presented at Research in Entrepreneurship VII, Budapest, 25-26 November, 1993.

Welsch, H., \& Roberts, J. (1994). Predictors of growth and expansion initiatives of Russian entrepreneurs in a postsocialist environment. In Paper presented at International Council of Small Business Strasbourg, 27-29 June 1994.

Welter, F. (2011). Contextualizing entrepreneurship_conceptual challenges and ways forward. Entrepreneurship: Theory and Practice, 35(1), 165-184.

Welter, F., \& Smallbone, D. (2010). The embeddedness of women's entrepreneurship in a transition context. In C. Brush, A. Bruin, E. Gatewood, \& C. Henry (Eds.), Women entrepreneurs and the global environment for growth: a research perspective (pp. 96-117). Northampton: Edward Elgar.

West, M. A., \& Anderson, N. R. (1996). Innovation in top management teams. The Journal of Applied Psychology, 81(6), 680-693.

Westhead, P., Ucbasaran, D., \& Wright, M. (2005). Decisions, actions and performance: do novice, serial and portfolio entrepreneurs differ? Journal of Small Business Management, 43(4), 393-417. 
Wong, A., Tjosvold, D., \& Liu, C. (2009). Innovation by teams in Shanghai, China: cooperative goals for group confidence and persistence. British Journal of Management, 20(2), 238-251.

Ylinenpåå, H., \& Chechurina, M. (2000). Perceptions of female entrepreneurs in Russia. In D. Deschoolmester (Ed.), in seminar proceedings Entrepreneurship under difficult circumstances. Best Paper in $30^{\text {th }}$ European Small Business Seminar. Belgium: Gent.

York, P. (2012). The sustainability formula. http://tccgrp.com/pdfs/SustainabilityFormula.pdf. Accessed 30 July 2012.

Zahra, S. A. (2005). Entrepreneurial risk taking in family firms. Family Business Review, 18(1), 23-40.

Zahra, S. A., Hayton, J. C., \& Salvato, C. (2004). Entrepreneurship in family vs. non-family firms: a resource-based analysis of the effect of organizational culture. Entrepreneurship: Theory \& Practice, 28(4), 363-381.

Zellweger, T., \& Sieger, P. (2012). Entrepreneurial orientation in long-lived family firms. Small Business Economics, 38, 67-84.

Zhuplev, A. (2009). Small business in Russia —-trends and outlook. Baltic Rim Economies, 5(October), 38-39.

doi:10.1186/2192-5372-3-8

Cite this article as: Gundry et al:: Women-owned family businesses in transitional economies: key influences on

firm innovativeness and sustainability. Journal of Innovation and Entrepreneurship 2014 3:8.

\section{Submit your manuscript to a SpringerOpen ${ }^{\circ}$ journal and benefit from:}

- Convenient online submission

Rigorous peer review

- Immediate publication on acceptance

- Open access: articles freely available online

- High visibility within the field

Retaining the copyright to your article

Submit your next manuscript at $\boldsymbol{\nabla}$ springeropen.com 